\title{
Üniversite Çalışanlarının Çok Yönlü Kariyer Tercihleri: Zaman Kullanım Eğilimi ve Kişilik Özellikleri Açısından Bir İnceleme ${ }^{1}$
}

(Araştırma Makalesi)

Protean Career Preferences of University Employees: An Investigation in Terms of Time Use Tendency and Personal Traits

Doi: 10.29023/alanyaakademik.824945

\section{Volkan ÖNGEL}

Doç. Dr., Beykent Üniversitesi, İktisadi ve İdari Bilimler Fakültesi, İktisat (Türkçe), volkanongel@beykent.edu.tr

ORCID No:0000-0001-8881-2465. 05354573409

\section{Hasan Sadık TATLI}

Arş. Gör., Beykent Üniversitesi, İktisadi ve İdari Bilimler Fakültesi, İşletme (İngilizce), hasantatli@beykent.edu.tr

ORCID No:0000-0003-1918-3188.05425640935

\section{Gökten ÖNGEL}

Uzman Dr, (Md., Phd.) İstanbul Ĕgitim ve Araştırma Hastanesi, Çocuk Să̆liğl ve

Hastalıkları,

goktenkorkmaz@yahoo.com

ORCID No:0000-0002-4165-3601.05323110430

\section{Murat SÜSL ̈̈}

Doktor Ögrretim Üyesi, Beykent Üniversitesi, İktisadi ve İdari Bilimler Fakültesi, Turizm ve Otel Isşletmeciliği,

msuslu@beykent.edu.tr

ORCID No: 0000-0002-3698-8634.05322154027

Bu makaleye atıfta bulunmak için: Öngel, V., Tatll, H. S., Öngel, G. \& Süslü, M. (2021). Üniversite Çalışanlarının Çok Yönlü Kariyer Tercihleri: Zaman Kullanım Eğilimi ve Kişilik Özellikleri Açısından Bir İnceleme. Alanya Akademik Bakış, 5(1), Sayfa No.1-20.

\begin{abstract}
ÖZET
Araştırmanın amacı, vakıf yüksekögretim kurumlarındaki akademik ve idari personellerin çok yönlü kariyer ĕgilimlerinde kişilik özelliklerinin ve zaman kullanım eğilimlerinin rolünün tespit edilmesidir. Araştırma kapsamında İstanbul'da yer alan üç vakıf yüksekögretim kurumundaki 387 personelden veri toplanmıştır. Araştırma sonucunda, akademik personeller ve idari personellerin demografik özelliklerinin kişilik özellikleri ve çok yönlü kariyer açısından anlaml farklılıklar meydana getirdiği tespit edilmişstir.
\end{abstract}

\footnotetext{
${ }^{1} \mathrm{Bu}$ makalede kullanılan veri toplama araçları Beykent Üniversitesi Rektörlüğünün 02.03.2020 tarihli Sosyal ve Beşeri Bilimler Yayın Etiği Kurul Üyeleri tarafından uygun görülmüştür.
} 
Anahtar kelimeler:

Çok yönlü kariyer,

A-B tipi kişilik,

Zaman kullanım

eğilimi,

Polikronik,

Monokronik.

Makale Geliş Tarihi:

12.11.2020

Kabul Tarihi:

25.11.2020

Keywords:

Protean career,

Type A-B personality,

Time-use tendency,

Polychronic,

Monochronic
Çalışanların zaman kullanım eğilimleri ile çok yönlü kariyer eğilimleri arasında anlamlı bir ilişki olmadiğı tespit edilmiştir. Çalışanların kişilik özellikleri ile çok yönlü kariyer eğilimleri arasında ise düşük düzeyde ilişki olduğu tespit edilmiştir. Zaman kullanım eğilimi ve kişilik özellikleri arasında ise düşük düzeyde ilișkiler tespit edilmiștir. Son olarak çalıșanların kişilik özelliklerinin A ya da B tipi olarak dağılmadı̆̆g, polikronik zaman kullanım eğilimlerinin yüksek olduğu ve çok yönlü kariyere olumlu yaklaştıkları tespit edilmiştir

\begin{abstract}
The study aims to determine the role of personality traits and time usage tendency in the protean career tendency of academic and administrative staff in foundation higher education institutions. In the study, data were collected from 387 personnel working in three foundation higher education institutions in Istanbul. Questionnaire forms were used to collect research data. As a result of the research, it was determined that academic and administrative staff's demographic characteristics create significant differences in terms of personality traits and protean career. It has been determined that there is no significant relationship between employees' time usage tendencies and protean career tendencies. It has been found that there is a low level of relationship between employees' personality traits and their protean career tendencies. Low-level relationships were found between time use tendency and personality traits. Finally, it has been determined that the employees' personality traits are not distributed as A or B type. They have high polychronic time usage tendencies, and they have a positive approach to a boundaryless career.
\end{abstract}

\section{GİRIŞ}

Son yıllarda çalışanların kariyer belirleme süreçleri klasik yaklaşım kalıplarının dışında gelişmektedir. Örgüt yapılarındaki değişmeler, sektörel hareketler, bilginin serbest dolaşımı ve bireysel özelliklere bağlı olarak çalışanlar farklı kariyer hedefleri belirleyebilmektedir. Kişisel özellikler ve zaman kullanım eğilimlerinin çalışanların kariyerler hedeflerini belirlemede önemli olduğu düşünülmektedir. Bazı çalışanlar kişilik özellikleri açısından iş yerlerinde sabit kalma eğiliminde olabilirken, bazı çalışanlar ise yeni firsatlara açık olabilmektedirler. Çalışanların kişilik bileşenleri ve zaman kullanım eğilimlerinde yer alan özellikler göz önüne alındığında "çalışanların çok yönlü kariyer seçeneğini tercih etmelerinde kişilik özellikleri ve zaman kullanım eğilimlerinin rolü nedir?” sorusuna cevap bulunması gerekmektedir. Söz konusu sorudan hareketle, araştırmanın amacı "vakıf yükseköğretim kurumlarındaki akademik ve idari personellerin çok yönlü kariyer eğilimlerinde personellerin kişilik özelliklerinin ve zaman kullanım eğilimlerinin rolünün tespit edilmesi" olarak belirlenmiştir. Alanyazında yer alan ve çalışanların çok yönlü kariyer seçimini aydınlatmaya çalışan araştırmaların, çalışanların zaman kullanım eğilimlerine odaklanmadığı görülmüştür. Çok yönlü kariyer seçimi hakkında yapılan çalışmaların kişilik özellikleri (Onay ve Vezneli, 2012), sınırsız kariyer (Kale ve Özer, 2012), kişi kültür uyumu (Onay ve Zel, 2011), işkoliklik (Kanbur ve Salihoğlu, 2014), özyeterlilik (Li vd. 2019), işten ayrılma niyeti, iş tatmini ve örgütsel bağl1lık (Redondo vd. 2019), mesleki kimlik (Hirschi vd. 2017) gibi konulara odaklandığı görülmektedir. Söz konusu araştırmalardan farklı olarak, bu araştırmada 
kişilik özellikleri ve zaman kullanım eğilimleri ile birlikte, çok yönlü kariyer eğilimleri incelenmektedir. Araştırmada elde edilen sonuçlar, çok yönlü kariyere yönelmesi muhtemel kişileri, kişilerin işle ilgili tercihlerini önceden tespit edebilme ve çok yönlü kariyer eğilimi olan kişilerin zaman kullanım alışkanlıklarını ve kişilik özelliklerini belirleyebilme açısından önemlidir. Araştırmada elde edilen sonuçlar incelenirken bazı kısıtların göz önünde bulundurulması gerekmektedir; araştırma keşfedici özelliğe sahiptir ve sonuçlar farklı değişkenlere göre yeniden değerlendirilebilir. Araştırmanın örneklemi üç vakıf yükseköğretim kurumundaki tam zamanlı görevli olan akademik ve idari personelleri kapsamaktadır. Örneklemin değişmesi araştırma sonuçlarının da farklılaşmasına neden olabilecektir. Araştırmada kullanılan ve çalışanların kişilik tiplerini belirlemek amacını taşıyan ölçeğin kişilik tiplerini yeterli düzeyde gösterme gücü olduğu düşünülmektedir. Araştırma, üniversitelerde görev alan akademik ve idari personellerin zaman kullanım eğilimleri ve kişilik tiplerinin kariyer seçimlerini ne şekilde yönlendireceği hakkında bulgular sunması açısından benzer çalışmalardan ayrılmaktadır.

\section{KAVRAMSAL ÇERÇEVE}

Araştırmanın bu aşamasında polikronik ve monokronik zaman kullanımı, A-B kişilik özellikleri ve çok yönlü kariyer niyeti hakkında tanımlamalara ve alanyazındaki çalışma bulgularına yer verilmektedir. Zaman kullanım eğilimleri ile ilgili birçok yaklaşım bulunmakla birlikte bu araştırma kapsamında zaman kullanım eğilimi polikronik ve monokronik sınıflandırma çerçevesinde incelenmektedir. Ayrıca, kişilik tipleri hakkındaki alan yazında geniş bir kullanıma sahip olan A ve B tipi kişilik tipleri, bu araştırma kapsamında indirgemecilikten uzak bir yaklaşımla, kişilerin iki özelliğin herhangi bir yerinde olabileceği de düşünülerek, zaman kullanım eğilimleri ile uyumlu şekilde ele alınmaktadır. Çok yönlü kariyer eğilimi, kişilik özellikleri ve zaman kullanım eğiliminin uyumlu olan özellikleri birlikte ele alınmaktadır. Son olarak alanyazında yer alan araştırma sonuçlarından yapılan çıkarımlardan hareketle oluşturulan hipotezler bu bölümde sunulmaktadır.

\subsection{Zaman kullanım eğilimi: Polikroniklik ve monokroniklik}

Zaman kullanım eğilimi, insanların aynı zaman diliminde birden fazla görev arasında geçiş yapmayı ne ölçüde tercih ettikleri ile ilgilidir. Polikronik davranış çalışanların aynı anda iki veya daha fazla işle uğraşması şeklinde tanımlanabilmektedir (Jang ve George, 2012: 588). Bunun tersi olan monokronik bireyler ise düşük katılım, bir seferde bir etkinlik zamanlama ve aynı anda çok fazla şey yapılması gerekiyorsa yönünü kaybetme ile karakterize edilebilmektedir. Örneğin, tek renkli bir kişiliğe sahip bireyler, aynı zaman bloğu için tek bir göreve veya projeye odaklanma eğilimindedir ve planlanmamış bir olayı (örn. telefon görüşmesi) kesinti olarak görürler. Öte yandan, polikronik bireyler çeşitli aktivitelere katılırlar. Polikronik oryantasyona sahip insanlar belirli bir zaman diliminde çeşitli görevler ve projeler arasında gidip gelmeyi öngörür. Planlanmamış olaylar, kesintiler; plandan veya programdan sapma yerine normal faaliyetlerin bir parçası olarak yorumlanır (Arndt vd., 2006: 320). Bireyin kişisel zaman stilinin monokronik / polikronik tarafı hakkındaki farkındalığının, zaman kullanımına ilişkin genel yaklaşımlarını, zaman baskısı algılarını ve görevlere harcanan zaman ve miktarları etkilemesi beklenir. Kişinin kendini iyi bir planlayıcı olarak düşünmesi veya yaptığı işleri zaman kaybı olarak görüp görmemesi kişisel verimlilik değerlendirmelerini etkiler (Scarborough ve Lindquist, 1998: 291). Polikronik kişilik özelliğine sahip çalışanların: çoklu görev (multi-tasking) alma ve görev değiştirme (taskswitching) özelliklerine sahip oldukları, monokronik bireyler için ise aynı zaman bloğunda 
sadece bir iş ya da görev yapmayı planladıkları, birden fazla iş ya da görev talebi gelmesi durumunda mutsuz olacakları söylenebilmektedir (Dalgıç ve Türkoğlu, 2018: 789).

\subsection{A-B tipi kişilik ve davranış özellikleri}

A-B kişilik tipleri Friedman ve Rosenman'ın 1974 yılındaki çalışmalarına dayanmaktadır. A tipi kişilik özelliklerine sahip bireyler; sürekli hareket ederler, hızlı yürür ve yerler, hızlı konuşurlar, sabırsızdırlar, iki şeyi aynı anda yaparlar, rekabeti severler, zaman baskısını hissederler ve başarıyı miktarı ile ölçerler. Nitelikten çok niceliği ön planda tutan A tipi kişilik sahipleri para-başarı-sorumluluk kavramlarını başarılarının simgesi olarak görürler ve bu nedenle zaman imkanlarının ötesinde bir programa sahip olmayı tercih ederler. B tipi kişilik özelliklerine sahip bireyler ise zaman ile ilgilenmez, sabırlıdır, eğlenmek için oyun oynar, suçluluk duymadan dinlenir, acelesi ve/veya işi bitirmek için zaman saplantıları yoktur. Rahat ve açık bireyler olarak nitelendirilebilen B tipi kişiliğe sahip bireyler başkaları ile yarışa girmez, sakin ve düzenli çalışmayı tercih ederler (Erdem vd., 2009: 107). Yapılan birçok çalışmada A tipi kişilik özelliklerine sahip olmak ve stres düzeyi arasında bağlantı olduğu bulunmuştur. Söz konusu kişilerin çok çalışan, zaman, nicelik ve sayılarla ilgili olarak kaygılar duyan, bir yandan kendilerinden emin görünürken, diğer yandan kendilerini önemli derecede eleştiren kişiler olduğu, sabırsızlık, rekabetçilik gibi özelliklerinin ve kişilerarası ilişkilerinde düşmanca yaklaşımlarının yanı sıra, kendileri hakkında yüksek beklentilere sahip oldukları, ben-merkezci davrandıkları ve sosyal açıdan sorunlu oldukları ifade edilmektedir (Şahin vd., 2011: 32).

Kişilik ve iş performansı ile ilgili ilişkiyi inceleyen endüstri psikoloji alanındaki çalışmaların konuyu özellikle 5 faktör kişilik kuramı içerisinde ele aldığı, A ve B tipi kişilik yapısı ile ilgili çalışmaların ise nispeten az olduğu söylenebilir (Koçak vd., 2017: 382). Bu kavramlar, 'zaman kişiliği', evdeki çalışma süresi ve zaman üzerindeki teknolojik etkiler tartışmalarıyla giderek daha önemli hale gelmektedir (Lindquist ve Scarborough, 2007). İnsanları birbirinden ayırt etmeye yarayan, her insanı benzersiz kılan, insanın kendisine özgü, kişiyi diğerlerinden ayıran özgün davranışların tümü kişilik olarak tanımlanabilmektedir (Tokat vd., 2013: 1975).

\section{3. Çok yönlü kariyer}

Sanayileşme döneminde, insanların çoğunlukla bir işletmede uzun süreli çalışma eğiliminde oldukları söylenebilmektedir. Kariyer, sanayi devri döneminde bir çalışanın bir ya da iki örgütte dikey olarak gelişimi şeklinde ifade edilmekteydi. Özellikle, çevrenin durağan ve rekabetin az olması çalışanların iş yaşamları boyunca birkaç örgüt içerisinde kariyer geliştirebilmelerine neden olmaktaydı. Çalışanların kariyerleri genellikle oldukça öngörülebilirdi (Suvacı ve Paşaoğlu Baş, 2018: 114). Kariyer kavramı ile ilgili olarak yapılmış tanımlamalar incelendiğinde; Arthur vd. (1989)'nin kariyer kavramını bireyin zaman içerisinde elde etmiş olduğu iş deneyimleri olarak ifade ettiği görülmektedir. Baruch ve Rosenstein (1992) tarafından yapılan tanımlamaya göre ise kariyer, bir çalışanın bir ya da daha fazla örgüt içinde elde etmiş olduğu gelişim sürecidir. Çalık ve Ereş (2006)'e göre kariyer, çalışanların işe yönelik olarak kazandıkları tutum ve davranışlardır. Ancak 1990'lı yıllardan sonra bireylerin demografik yapıları ile birlikte yönetim ve örgüt yapılarının da değişmeye başlaması geleneksel kariyer yapıları yerine yeni kariyer yaklaşımlarını ortaya çıkarmaya başlamıştır. Zamanla çalışanlar daha özgür, göreceli olarak bağımsız hale gelmeye başlamıştır (Erdoğmuş, 2003; Seymen, 2004). Küreselleşmenin getirmiş olduğu değişimlere bağlı olarak kariyer yaklaşımlarında da farklılaşmalar olmuştur. Geleneksel kariyer 
yaklaşımlarından farklı olarak yeni kariyer yaklaşımlarına göre, çalışanlar sektörel ve organizasyonel değişimlere daha açık olabilmektedirler. Ayrıca çalışanlar değişimlere daha kolay ayak uydurabilmektedirler.

Yeni kariyer yaklaşımlarından birisi olan çok yönlü kariyer kavramı, çalışanlarda psikolojik bir kökene sahiptir (Inkson, 2006: 58). Hall $(1996,2004)$ tarafindan yapılan tanımlamaya göre, çok yönlü kariyer "bireyin kendi kariyeri üzerinde kontrol sahibi olması ve kariyerini kendi değerleri ile yönlendirmesidir”. Çok yönlü kariyer bireyin ve çevrenin etkisi ile değişen ve zaman içerisinde birey tarafindan yeniden kurulan bir yapıya odaklanmaktadır. Alanyazında çok yönlü kariyer iki farklı boyut üzerinden incelenmektedir; kendi kendini yönlendiren kariyer ve değer yönelimli kariyer. Kendi kendini yönlendiren kariyer Direnzo ve Greenhaus, (2011) tarafından, bireyin kariyerinde söz hakkının bireyin kendisinde olması olarak tanımlanmaktadır. Kendi kendini yönlendiren kariyer düşüncesinde çalışanlar kendi kariyerlerinin sorumluluğunu alarak gelişimlerini sağlama ve hedeflerine ulaşmada yüksek motivasyona sahip olmaktadır. Kendi kendini yönlendiren kariyerde çalışanlarını yönlendiren düşünce, başarma, ilerleme gibi unsurlardır. Değer odaklı kariyer düşüncesi, Redondo vd. (2019) tarafından, çalışanların içsel değerlerine uygun organizasyonlar arama düşüncesi olarak tanımlanmaktadır. Burada söz konusu değerler kişisel idealler ve prensiplerdir.

Geleneksel kariyerden farklı olarak bireyin yapmış olduğu psikolojik sözleşme örgütle değil, bireyin kendisi ile yapılan içsel bir anlaşmadır (Hall, 1996). Çok yönlü kariyerde çalışanlar kişisel gelişimlerini sağlamaya odaklanırlar (Kale ve Özer, 2012: 175). Ayrıca çok yönlü kariyer otonomi temellidir. Bu yönelime sahip çalışanlar tutkularını izleme, proaktif olma, kendini gerçekleştirme adına adım atabilmektedirler (Briscoe vd. 2006; Direnzo vd., 2015; Herrman vd. 2015).

\subsection{Kavramlar arası ilişkiler ve araştırma hipotezlerinin geliştirilmesi}

Conte ve Jacobs (2003) tarafından yapılan araştırmada, bireylerin zaman kullanım eğilimleri ile kişilik özellikleri arasındaki ilişkilerin incelenmesi amaçlanmıştır. Araştırma sonuçlarına göre, polikroniklik ile gecikme, performans denetimi ve vicdanlılık arasında anlamlı ilişkiler olduğu tespit edilmiştir. Conte ve Gintoft (2005) tarafından yapılan çalışmada ise çalışanların kişilik özellikleri açısından zaman kullanım eğilimleri ve performansları arasındaki ilişkilerin tespit edilmesi amaçlanmıştır. Çalışmanın bulguları, çalışanların kişilik özellikleri ile zaman kullanımı ve performansları arasında anlamlı ilişkiler olduğu şeklindedir. Schein (1992) araştırmasında, zaman kullanım eğilimi ile kişilik özellikleri arasındaki ilişkinin tanımlanması amaçlanmıştır. Araştırma sonucunda, zaman kullanım eğiliminin kişilik türleri ile ilişkili olduğu, dışadönük ve deneyime açık kişilerin çoklu görev gerçekleştirmede daha iyi olduğu sonucuna ulaşılmıştır. Kantrowitz vd. (2012) çalışanların performanslarının zaman kullanım eğilimi ve kişilik özellikleri ile olan ilişkisinin incelenmesini amaçlamışlardır. Çalışmanın bulgularına göre; zaman kullanım eğilimi ile yenilikçilik, rekabet etme, duygusal kontrol, iyimserlik ve toplam iş performansı arasında olumlu yönde ilişkiler tespit edilmiştir. Frei vd. (1998) tarafından yapılan araştırmada zaman kullanım eğilimi ile kişilik tiplerinin ilişsisi, verimlilik, stres arasındaki ilişkilerin tespit edilmesi amaçlanmıştır. Araştırma sonucunda kişilik tipinin zaman kullanım eğilimi ile ilişkili olduğu, A tipi kişilerin beklenenin aksine çoklu zaman kullanımı düzeyinin az olduğu, daha çok tekli zaman kullanımı eğiliminin yüksek olduğu sonucuna ulaşılmıştır. Ayrıca A tipi ve tekli zaman kullanımı eğiliminde olan çalışanların stres düzeylerinin yüksek, etkinlik düzeylerinin ise artış eğiliminde olduğu 
sonucuna ulaşılmıştır. Bahsi geçen çalışmalar neticesinde çalışanların zaman kullanım eğilimleri ile kişilik tipleri arasındaki ilişkiye yönelik olarak kurulan hipotez aşağıdaki şekildedir;

H1: Çalışanların zaman kullanım eğilimleri ile kişilik tipleri arasında anlamlı bir ilişski vardir.

Rastgar vd. (2014) araştırmasında, kişilik türleri ile sınırsız ve çok yönlü kariyer tercihleri arasındaki ilişkilerin tespit edilmesi amaçlanmıştır. Araştırma sonucunda, çok yönlü kariyer eğilimi ile kişilik türleri arasında anlamlı ilişkiler tespit edilmiştir. Yeniliklere açık ve dişa dönük olan çalışanların çok yönlü kariyer yapma eğilimi daha yüksekken, kabullenici ve uyumlu kişilik yapısındaki çalışanların ise çok yönlü kariyer eğilimi düşük olarak tespit edilmiştir. Kaspi-Baruch (2016) tarafından yapılan araştırmada, çalışanların kişilik özelliklerinin kariyer yönelimi ile olan ilişkisinde motivasyonun aracıllk rolünün tespit edilmesi amaçlanmıştır. Araştırma bulgularına göre çalışanların kişilik yapılarının çok yönlü ve sınırsız kariyer seçimi ile ilişkili olduğu sonucuna ulaşılmıştır. Girişimci ve yeniliğe açık olarak tanımlanan kişilerin çok yönlü kariyer eğiliminde artış, olumsuz yaklaşıma sahip kişilerin aynı örgütte kalma niyetinde artış tespit edilmiştir. Gökdeniz ve Merdan (2011) tarafından yapılan araştırmada kişilik özellikleri ile kariyer seçimi arasındaki ilişkilerin tespit edilmesi amaçlanmıştır. Araştırma sonucunda çalışanın yenilikçi yapıda olması ile rekabetçi kariyer, istikrarlı kariyer ve girişimci kariyer eğilimleri arasında anlamlı ilişkiler olduğu tespit edilmiştir. Söz konusu çalışmalar göz önüne alınarak çalışanların çok yönlü kariyer tercihleri ile kişilik tipleri arasındaki ilişkiye yönelik olarak kurulan hipotez aşağıdaki şekildedir;

H2: Çalışanların çok yönlü kariyer tercihleri ile kişilik tipleri arasında anlamlı bir ilişki vardir.

Alanyazında yer alan çalışmalar incelendiğinde zaman kullanım eğilimi ve çok yönlü kariyer arasındaki ilişkileri inceleyen bir çalışma olmadığı görülmektedir. Bu yüzden söz konusu değişkenler arasındaki ilişkilerin kavramsal arka planı değişkenlerin içeriklerine bağlı olarak oluşturulmaktadır. Polikronik zaman kullanımının aynı anda birden çok işe uyum sağlaması, farklı görevler hakkındaki gelişimlerinin artmasını sağlayabilir. Çalışanın farklı işler hakkındaki bilgilerinin gelişmesi, yeni bilgilere açık olması çok yönlü kariyer ile açıklanabilmektedir. Jang ve George (2012)'a göre, polikronik eğilimde olan kişilerin işten elde ettikleri doyum yüksek olduğunda çalışanların farklı görev ve iş arayışı azalmaktadır. Çoklu yönlü kariyerde, çalışanlar yetenek ve bilgilerini geliştirmek için arzuludurlar. Söz konusu arzular bireyin farklı işler yapabilmesine ve/veya farklı işler arasında geçiş yapabilmesine olanak sağlayabilmektedir. İşler arasındaki geçiş ise polikronik zaman kullanımı ile açıklanmaktadır. Bluedorn vd. (1999)'ne göre polikronikliğin iki temel karaketeristiği çalışanın birden fazla görevi alabilmesi ve görevler arasında geçiş yapabilmesidir. Arndt vd. (2006) tarafından çalışanların zaman kullanım eğilimleri ile iş doyumlarının arasındaki ilişkileri tespit etmek amacıyla yapılan araştırma sonucunda çalışanların polikroniklik düzeylerinin yüksek olmasının çoklu görevleri yerine getirmede temel unsur olduğu, görevleri etkin yönetmede pozitif yönde çıktı sağladığı, iş memnuniyetini arttırdığı sonucuna ulaşılmışıı. Ayrıca çalışanların iş-görev değiştirme eğilimlerinin daha yüksek olduğu sonucuna ulaşılmıştır. Çok yönlü kariyer ve zaman kullanım eğilimlerinin kavramsal yapılarına bağlı olarak oluşturulan varsayımsal ilişkilerden hareketle kurulan hipotez aşağıdaki şekildedir; 
H3: Çalışanların çok yönlü kariyer tercihleri ile zaman kullanım ĕgilimleri arasında anlamlı bir ilişki vardır.

\section{ARAŞTIRMANIN METODOLOJISI}

Araştırmanın metodolojisi kısmında, araştırmanın hangi amaçla yapıldı̆̆ 1 ve elde edilecek olan sonuçların önemliliği, araştırmanın evreni, araştırma evreninden seçilen örneklem, örneklemi belirlemede kullanılan örnekleme yöntemi hakkında bilgilere yer verilmektedir. Ayrıca araştırmada kullanılan veri toplama araçları ve verilerin toplanma süreci hakkında ayrıntılara yer verilmektedir. Söz konusu bilgilerle, araştırma sürecinin şeffaf şekilde açıklanması sağlanmaktadır.

\subsection{Araştırmanın amacı ve önemi}

Endüstri toplumuna geçişin ilk yıllarında çalışanların genellikle bir organizasyonda sabit bir kariyer eğiliminde olduğu görülmekteydi. Ancak enformasyon teknolojilerinde meydana gelen değişimler ve buna bağlı olarak organizasyon yapılarının farklılaşması çalışan davranışlarında değişimine neden olmuştur. Erdoğmuş (2003), söz konusu değişimlerin çalışanları daha özgür hale getirdiğini savunmaktadır. Bilginin çok kolay şekilde yayılıyor olması, çalışanların diğer örgütler ve çalışanların davranışları hakkında fikir edinmesini kolaylaştırmakta, sektörel rekabet de göz önüne alındığında çalışanların davranışları daha bağımsız olabilmektedir. Çalışanların kariyerlerinde söz sahibi olması ve kariyerinde otonomiyi sağlaması çok yönlü kariyer olarak ifade edilmektedir (Hall, 1996;2004; Briscoe ve Hall, 2006). Bireyin kişisel özelliklerinin de göz önüne alınması kariyer yollarının belirlenmesinde önem teşkil edebilmektedir. Kişilik özellikleri ve zamanlama eğilimi, yapılan iş ile ilişkili olarak görülmektedir (Şahin vd. 2011: 32). Çalışanların zaman eğilimi, kişilik özellikleri ve kariyer belirlemesi hakkındaki alanyazından hareketle araştırmanın sorusu; "çalışanların çok yönlü kariyer seçeneğini tercih etmelerinde kişilik özellikleri ve zaman kullanımı eğilimlerinin rolü nedir?” şeklinde oluşturulmuştur. Bunun yanında araştırmada çalışanların mesleki özelliklerinin zaman kullanım eğilimi, kişilik özellikleri ve kariyer seçimleri açısından önemli olabileceği düşünülebilir. Söz konusu düşünceden hareketle aynı sektör içerisinde görevli, farklı mesleki dinamiklere sahip çalışanların incelenmesinin doğru olacağı düşüncesi ile araştırmanın amacı "vakıf yükseköğretim kurumlarındaki akademik ve idari personellerin çok yönlü kariyer eğilimlerinde, personellerin kişilik özelliklerinin ve zaman kullanım eğilimlerinin rolünün tespit edilmesi” olarak belirlenmiştir. Akademik ve idari personellerin aynı organizasyon içesinde yer alan kişiler olmasına rağmen farklı rol dinamiklerine sahip olması araştırma kapsamında incelenmelerini sağlamaktadır. Böylece aynı örgüt içinde yer alan farklı rol sahibi çalışanların kariyer seçimlerinde nasıl bir farklılık/benzerlik meydana geldiği de tespit edilebilecektir. Araştırma sonucunda elde edilecek bulgular çalışanların zaman kullanım eğilimleri ve kişilik özellikleri açısından nasıl bir kariyer geliştirme eğiliminde olduklarının belirlenmesi açısından önem taşımaktadır. Elde edilecek sonuçlar özellikle kişilerin ilerleyen dönemlerde kariyerlerini nasıl yönlendireceklerini öngörme açısından önem taşımaktadır. Böylece örgütler iş dinamiklerine uygun personelleri seçemediğinde, personellerin örgüt ve görev değişimi gibi eğilimlerini öngörebilir ve buna uygun seçimlere yönelebilir. Ayrıca ulaşılacak sonuçlar akademik alanyazında kariyer seçimlerini ve personel davranışlarını modelleyen araştırmalar için ise önemli/önemsiz olan faktörlerin tespit edilmesi açısından faydalı olabilecektir. 


\subsection{Araştırmanın evreni, örneklemi ve örnekleme yöntemi}

Araştırmanın evreni, vakıf yükseköğretim kurumları çalışanlarından oluşmaktadır. Vakıf yükseköğretim kurumlarında çalışan akademik ve idari personellerin farklı kurumlara geçiş yapabilme ihtimallerinin her zaman mevcut olması, özellikle akademik personellerin öğretim, bilimsel araştırma ve yöneticilik (bölüm başkanlığı, dekanlık, müdürlük vb.) gibi farklı görevleri aynı anda gerçekleştirmelerinin, kişilik özellikleri ve zaman kullanım eğilimlerinin bir sonucu olabileceği düşünülebilir. Araştırmanın örneklemini ise, İstanbul'da yer alan üç vakıf yükseköğretim kurumunda görevli akademik ve idari personeller oluşturmaktadır. Seçilen kurumların veri toplama için izin sağlamış olması, kurum çalışanlarının örneklem olarak seçilmesinde önemli bir unsur olmuştur. Örneklemin seçiminde ise basit tesadüfi örneklem tekniği kullanılmıştır. Basit tesadüfi örnekleme Kurtuluş (2014) tarafından, örneklemdeki her bir bireyin eşit seçim şansının olduğu, seçime bağlı olarak meydana gelen hatanın azaldığı, örneklemin kolayca listelenebildiği örnekleme türü olarak tanımlanmaktadır. Söz konusu özelliklere bağlı olarak vakıf eğitim kurumlarındaki akademik ve idari personelin mail listelerine ulaşılmış ve içerisinden rastgele seçim yapılmıştır. Anket formunun katılımcılara gönderimi öncesinde araştırmanın etik değerlere uygun olduğunu gösteren etik kurul onayı 02.03.2020 tarihinde alınmıştır. Ayrıca oluşturulan çevrimiçi anket formları ile 03.03.2020 - 11.03.2020 tarihleri arasında katılımcılara ulaşılmaya çalışılmıştır. Akademik ve idari personellerin yakın sayıda katılım sağlayabilmesi için rasgele seçilen 250 akademik personel ve 250 idari personele mail ile anket formu gönderilmiştir. Gönderilen anket formalarına 183 idari ve 204 akademik personel tarafından dönüş sağlanmıştır. 387 katılımcı ile anketin veri toplama süreci sonlandırılmıştır. Örneklem sayısının belirlenmesinde 384 sınırı ve madde başına (30 madde) 10 katılımcı kısıtları göz önüne alınmıştır. Yapılacak analizlerin örneklem sayısına duyarlı olması, anlamsız ilişkilerin anlamlı hale gelebilmesi durumu da göz önüne alınarak daha fazla katılımcıya ulaşılmamıştır.

\subsection{Araştırmanın veri toplama araçları ve veri toplama süreci}

Üç vakıf yükseköğretim kurumunda yer alan akademik ve idari personellerin katılımı ile gerçekleştirilen bu araştırmada veri toplama esnasında çevrimiçi anket formu kullanılmıştır. Anket formu dört bölümden oluşmaktadır. Anket formunun ilk kısmında Lindquist ve Scarboruogh (2007) tarafından oluşturulan zaman kullanım eğilimi ölçeği kullanılmıştır. Zaman kullanım eğilimi ölçeği 5 maddeden oluşmaktadır. Ölçekte yer alan maddelere cevaplar 7'li likert tipi ölçüm ile sağlanmıştır. Anket formunun ikinci kısmında Karlberg vd. (1997) tarafından oluşturulan ve alanyazında birçok kez kullanılmış kişilik tipleri ölçeği yer almaktadır. Ölçek 11 maddeden oluşmaktadır. Ölçekte yer alan maddelere cevaplar 7'li likert tipi ölçüm ile sağlanmıştır. Anket formunun üçüncü bölümünde Briscoe vd. (2006) tarafından oluşturulan Paksoy vd. (2017) tarafindan kullanılan çok yönlü kariyer tutumu ölçeği yer almaktadır. Ölçek 14 maddeden ve iki boyuttan oluşmaktadır. Ölçeğin kendi kendini yönlendiren kariyer boyutu 8 maddeden oluşurken, değer yönelimli kariyer boyutu ise 6 maddeden oluşmaktadır. Ölçekte yer alan maddelere cevaplar 7'li likert tipi ölçüm ile sağlanmıştır. Anket formunun son kısmında ise akademik ve idari personelin tanımlayıcı özelliklerine ait sorular (cinsiyet, yaş, medeni durum, eğitim düzeyi, görev türü, kişinin hayatının büyük kısmını geçirdiği şehir) yer almaktadır.

Anket formlarının uygun doldurulma durumunun değerlendirilmesinde Hair vd. (2014)'nin belirtmiş olduğu veri ayıklama süreci takip edilmiştir. Hair vd. (2014)'ne göre anket formalarında büyük eksiklik söz konusu olmadığında ve uç değerlerin popülasyonu yansıttığı 
durumlarda veri ayıklama sürecine gerek kalmamaktadır. Ayrıca anket formuna verilen cevapların uygunluğunu inceleyebilmek için kontrol ifadesi (örnek kontrol ifadesi; bu ifadeyi okuduğunuzda 1 seçeneğini işaretleyiniz) kullanılmıştır. Katılımcılar tarafindan verilen cevapların bariz bir şekilde olumsuzluk içermemesi (örneğin; standart şekilde tüm sorulara tek şık işaretleme yapılmamış olması ve kontrol sorusuna uygun cevaplar verilmiş olması) ve boş bırakılan madde olmamasına bağlı olarak ayıklama süreci işletilmemiştir. Verilerin uygun şekilde toplandığı sonucuna ulaşıldıktan sonra ise verilerin analizine geçilmiştir.

\section{ARAŞTIRMANIN BULGULARI}

Araştırmanın bulguları kısmında, araştırmanın örneklemi ve ölçüm araçlarının uygunluğunun tespit edilmesi için yapılan faktör analizi ve güvenilirlik analizi bulgularına yer verilmektedir. Ayrıca araştırmanın örnekleminde yer alan katılımcıların tanımlayıcı özellikleri ve anket formunda yer alan maddeler hakkındaki görüşlerini ifade eden istatistiklere yer verilmektedir. Son olarak, bağımsız örneklem t-testi ve korelasyon analizi sonuçlarına da bu bölümde yer verilmektedir.

\section{Faktör analizi}

Faktör analizi, çok sayıdaki değişkenin az sayıdaki değişkenler ile temsil edilmesini sağlayan, ölçüm araçlarının araştırmada kullanımının uygunluğunu tespit etmede kullanılan bir analiz türüdür (Hair vd. 2014). Faktör analizinde ölçeklerin KMO değeri, Bartlett's küresellik testi ve açıklanan toplan varyans değerleri önemli olarak görüldüğü için bu araştırmada yapılan faktör analizi sonuçları tablolaştırılmıştır. KMO değeri, Bartlett's küresellik testi ve açıklanan toplan varyans değerleri için sonuçların uygunluğunda Kurtuluş (2014) ve Hair vd. (2014) tarafından uygun görülen sınır değerleri kullanılmaktadır. Uygun görülen sınır değerleri KMO için yaklaşık olarak; 0,600, Bartlett's küresellik testi anlamlılık; $p<0,050$ ve açıklanan toplam varyans için yaklaşık \%60’tır.

Tablo 1. Faktör analizi sonucları

\begin{tabular}{|l|l|l|l|}
\hline Ölçek & KMO & $\begin{array}{l}\text { Bartlett's testi } \\
\text { (anlamllık) }\end{array}$ & $\begin{array}{l}\text { Açılanan toplam } \\
\text { varyans }\end{array}$ \\
\hline $\begin{array}{l}\text { Zaman kullanım } \\
\text { eğilimi }\end{array}$ & 0.878 & 0.000 & 71.47 \\
\hline Kişilik tipleri & 0.697 & 0.000 & 57.18 \\
\hline Çok yönlü kariyer & 0898 & 0.000 & 56.57 \\
\hline
\end{tabular}

Araştırmada kullanılan ölçüm araçlarının faktör analizi sonuçları Tablo 1'de yer almaktadır. Zaman kullanımı eğilimi ölçeğinin KMO değeri (0.878), anlamlılık seviyesi $(0.000<p<0.050)$ ve açıklanan toplam varyans (\%71.47) değerlerinin sınır değerlerinin yeterince üzerinde olduğu ve araştırmada kullanılmaya uygun olduğunu ifade etmek mümkündür. Kişilik tipleri ölçeğinin KMO değeri (0.697), anlamlılık seviyesi $(0.000<\mathrm{p}<0.050)$ ve açıklanan toplam varyans (\%57.18) değerlerinin sınır değerlerine yakın olduğu görülmektedir. Son olarak çok yönlü kariyer ölçeğinin KMO değeri $(0.898)$ ve anlamlılık seviyesi $(0.000<p<0.050)$ değerlerinin sınır değerlerine uygun olduğunu ifade etmek mümkündür. Açıklanan toplan varyans değerinin (\%56.57) ise sınır değerine yakın olduğu görülmektedir. Maddelerin silinmesinin açıklanan toplan varyansı yükseltirken KMO değerini düşürmesi, madde atarak değerleri yükseltmeyi engellemektedir. Ayrıca Hair vd. (2014) tarafindan, madde silinmesi ve faktör analizi değerlerinin iyileştirilmesinde en önemli unsur olarak "alanyazına uygunluk" görülmektedir. Ölçüm araçlarının sınır değerlerine yakın olması, ölçüm araçlarında yer alan 
maddelerin alanyazında önemli olması ve çapraz kontrollerde güvenilirlik değerlerinin etkilenecek olmasına dayanarak mümkün olduğu kadar madde silinmemiştir. Çok yönlü kariyer ölçeğindeki "Başkalarının, kariyerime ilişkin seçimlerimi nasıl değerlendirdikleri benim için çok da önemli değildir." Maddesi faktör analizinde uygun dağılım sağlamama, güvenilirlik değerini yüksek derecede olumsuz şekilde etkileme gibi nedenlerle analiz kapsamı dışında bırakılmışırı. Faktör analizi sonucunda elde edilen değerlerin sınır değerlerine yakın olmasına dayanarak ölçüm araçlarının araştırmada kullanılması uygun olduğuna karar verilmiştir. Faktör analizi sonucunda zaman kullanım eğilimi tek faktörde toplanmıştır. Kişilik tipleri ölçeğindeki maddeler aceleci ( 3 madde), stresli (3 madde), zaman baskısı ( 3 madde) ve özgüven ( 2 madde) olarak faktörlere ayrılmıştır. Çok yönlü kariyer ölçeği ise kendi kendini yönlendiren kariyer ( 8 madde) ve değer yönelimli kariyer (5 madde) olarak faktörlere ayrılmıştır.

\section{Güvenilirlik analizi}

Araştırmada kullanılan ölçüm araçlarına katılımcılar tarafindan verilen cevapların güvenilirliğini tespit edebilmek için yapılan güvenilirlik analizinde Cronbach's Alpha katsayısı kullanılmıştır. Katsayının sınır değeri için Kurtuluş (2014) ve Hair vd. (2014) tarafindan uygun görülen sınır değerleri (Cronbach's Alpha >0,600) kullanılmıştır.

Tablo 2. Güvenilirlik analizi sonuçları

\begin{tabular}{|l|l|l|}
\hline Ölçek & Cronbach's Alpha değeri & Madde sayıs1 \\
\hline Zaman kullanım eğilimi & 0.900 & 5 \\
\hline Kişilik tipleri & 0.630 & 11 \\
\hline Çok yönlü kariyer & 0.890 & 13 \\
\hline
\end{tabular}

Araştırmada kullanılan ölçeklerin güvenilirlik analizlerinin sonucunda elde edilen katsayılar Tablo 2'de yer almaktadır. Zaman kullanımı eğilimi ölçeğinin güvenilirlik katsayısı 0,900 düzeyinde olduğu, kişilik tipleri ölçeğinin güvenilirlik katsayısı 0,630 düzeyinde olduğu ve çok yönlü kariyer ölçeğinin güvenilirlik katsayısı ise 0,890 düzeyinde olduğu görülmektedir. Çok yönlü kariyer ölçeğinde yer alan bir madde faktör analizi esnasında araştırma kapsamından çıkarıldığı için güvenilirlik analizine dahil edilmiştir.

\section{Tanımlayıc istatistikler}

Araştırmanın bu kısmında, katılımcıların ölçüm araçlarındaki maddelere vermiş oldukları cevapların ortalaması (Tablo 3) ve katılımcıların demografik özellikleri (Tablo 4) hakkında bilgiler yer almaktadır.

Tablo 3. Tanımlayıcı istatistikler

\begin{tabular}{|l|l|l|l|}
\hline Ölçüm aracı & Ortalama & Kişi & Std. Sapma \\
\hline Zaman kullanım eğilimi & 4.4842 & 387 & 1.61465 \\
\hline Aceleci & 3.4978 & 387 & 1.30637 \\
\hline Stresli & 4.0293 & 387 & 1.35995 \\
\hline Zaman baskısı hisseden & 2.9406 & 387 & 1.20624 \\
\hline Özgüvenli & 3.3708 & 387 & 1.22055 \\
\hline Kendi kendini yönlendiren kariyer & 5.5685 & 387 & 1.16230 \\
\hline Değer yönelimli kariyer & 5.2972 & 387 & 1.14876 \\
\hline
\end{tabular}

Katılımcıların verdikleri cevapların ortalaması ile ilgili bulgular Tablo 3 'te yer almaktadır. Tabloda yer alan bulgulara göre katılımcıların zaman kullanım eğilimlerinin polikroniklik 
seviyesinde olduğu görülmektedir. Katılımcıların bir zaman diliminde birden fazla işle uğraşabilme eğiliminde olduğunu ifade etmek mümkündür. Katılımcıların kişilik özellikleri incelendiğinde, çalışanların aceleci kişiler oldukları, stres seviyelerinin yüksek olduğu ve zaman baskısını az düzeyde hissettikleri görülürken, özgüven konusunda ise kararsız düzeyde oldukları tespit edilmiştir. Katılımcıların kariyerlerinin kendi ellerinde olduğunu ve kariyerlerini yönlendirmede içsel unsurların önemli olduğunu düşündükleri görülmektedir. Çalışanların yüksek düzeyde çok yönlü kariyer eğiliminde olduklarını ifade etmek mümkündür. Bulgular birlikte yorumlandığında, kişilik özelliklerinin baskın bir yönünün olmadığı bu yüzden çoklu kişilik yaklaşımının görüldüğü, çalışanların çoklu zaman kullanımı eğilimlerinin baskın olduğu ve çok yönlü kariyer eğilimlerinin olduğunu ifade etmek mümkündür. Ancak çalışanların kişilik özelliklerinde zaman baskısının yüksek bir değer almamış olması, zaman kullanım eğilimlerinin kişilikten ziyade işin dinamikleri ile ilgili olduğunu düşünmeye neden olmaktadır. Çalışanlar işin dinamiklerinden dolayı aynı anda çoklu görev (multi-tasking) ya da görev değişimi (switch-tasking) eğiliminde olabilirler. Son olarak tanımlayıcı istatistiklere göre katılımcıların salt olarak A ya da B tipi kişilik özelliklerine sahip olmadığı görülmektedir. Moorhead ve Griffin (1992) bireylerin çok nadir olarak A ya da B tipi kişilik özelliklerinden birisini net olarak taşıdığını ifade etmektedir. Bireyler genellikle bu kişilik tiplerinin bazı özelliklerini daha fazla taşıyabilmektedirler. Yani bireyler aslında A-B kişilik tiplerinden çok kişilik tiplerinin bazı özelliklerini gösterme eğiliminde olabilmektedir.

Tablo 4. Demografik özellikler

\begin{tabular}{|c|c|c|c|}
\hline Değişken & Özellik & Kişi & $\%$ \\
\hline \multirow{2}{*}{ Cinsiyetiniz } & Erkek & 158 & 40.8 \\
\hline & Kadın & 229 & 59.2 \\
\hline \multirow{5}{*}{ Yaşınız } & 25 yaş ve altında & 77 & 19.9 \\
\hline & 26- 30 yaş aralığında & 82 & 21.2 \\
\hline & 31-35 yaş aralığında & 67 & 17.3 \\
\hline & $36-40$ yaş aralığında & 69 & 17.8 \\
\hline & 41 yaş ve üzeri & 92 & 23.8 \\
\hline \multirow{2}{*}{ Medeni durumunuz } & Evli & 176 & 45.5 \\
\hline & Bekar & 211 & 54.5 \\
\hline \multirow{3}{*}{ Eğitim durumunuz } & Lise & 31 & 8.0 \\
\hline & Üniversite & 154 & 39.8 \\
\hline & Lisansüstü & 202 & 52.2 \\
\hline \multirow{2}{*}{ Görev tanımı } & Akademik personel & 204 & 52.7 \\
\hline & İdari personel & 183 & 47.3 \\
\hline \multirow{3}{*}{$\begin{array}{l}\text { Yaşamınızın çoğunluğunu } \\
\text { geçirdiğiniz şehir neresidir? }\end{array}$} & İstanbul & 298 & 77.0 \\
\hline & Diğer & 89 & 23.0 \\
\hline & Total & 387 & 100.0 \\
\hline
\end{tabular}

Araştırma kapsamında yer alan akademik personeller ve idari personellerin demografik özellikleri ile ilgili bilgiler Tablo 4'te yer almaktadır. Katılımcıların \%40.8'i erkek, \%59.2'si kadınlardan oluşmaktadır. Katılımcıların \%19.9'u 25 yaş ve altında, \%21.2'si 26-30 yaş aralığında, \%17.3'ü 31-35 yaş aralığında, \%17.8'i 36-40 yaş aralığında ve \%23.8'i 41 yaş ve üzerindeki çalışanlardan oluşmaktadır. Katılımcıların \%45.5'i evli, \%54.5'i ise bekar çalışanlardan oluşmaktadır. Katılımcıların eğitim özellikleri incelendiğinde, \%8'inin lise, $\% 39.8$ 'inin üniversite, \%52.2'sinin lisansüstü seviyede eğitime sahip olduğu görülmektedir. Katılımcıların \%52.7'si akademik personellerden, \%47.3'ü ise idari personellerden 
oluşmaktadır. Son olarak katılımcıların hayatlarının çoğunu geçirdiği yer \%77 İstanbul, \%23 ise diğer şehirler olarak görülmektedir.

\section{Bă̆ımsız örneklem t-testi}

Araştırmaya katılan idari ve akademik personellerin zaman kullanım eğilimleri, kişilik türleri ve çok yönlü kariyer eğilimlerindeki farklılıkların tespit edilmesi amacıyla yapılan bağımsız örneklem T-Testi sonuçları Tablo 5'te yer almaktadır. Tabloda yer alan bilgilerin yorumlanması için anlamlılık değeri $\mathrm{p}<0.050$ (\%95 güven aralığı ve $\% 5$ hata payı) esas alınmaktadır. Ancak T-testinin çift kuyruk değeri sağlamasından dolayı analiz sonuçlarının yorumlanmasında $\mathrm{p}<0.025$ değeri göz önüne alınmaktadır. Tabloda yalnızca anlamlı farklılıklara yer verilmiş ve sonuçlar birleştirilerek tablolaştırılmıştır.

Tablo 5. Bağımsız örneklem t-testi sonuçları

\begin{tabular}{|c|c|c|c|c|c|c|}
\hline \multirow{2}{*}{$\begin{array}{l}\text { Demografik } \\
\text { özellik }\end{array}$} & \multirow[b]{2}{*}{ Değişkenler } & & \multicolumn{2}{|c|}{$\begin{array}{l}\text { Ortalamaların eşitliği } \\
\text { için t-testi }\end{array}$} & \multirow[b]{2}{*}{ Özellik } & \multirow[b]{2}{*}{ Ort. } \\
\hline & & & $\mathrm{t}$ & $\begin{array}{l}\text { Anlamlılık } \\
\text { (2-kuyruk) }\end{array}$ & & \\
\hline \multirow{8}{*}{ Görev türü } & \multirow{2}{*}{ Aceleci } & $\begin{array}{l}\text { Varyansların } \\
\text { Eşitliği }\end{array}$ & 2.387 & .017 & Akademik & 3.6471 \\
\hline & & $\begin{array}{l}\text { Varyansların } \\
\text { Eşitsizliği }\end{array}$ & 2.393 & .017 & İdari & 3.3315 \\
\hline & \multirow{2}{*}{ Stresli } & $\begin{array}{l}\text { Varyansların } \\
\text { Eşitliği }\end{array}$ & -2.844 & .005 & Akademik & 3.8448 \\
\hline & & $\begin{array}{l}\text { Varyansların } \\
\text { Eşitsizliği }\end{array}$ & -2.872 & .004 & İdari & 4.2350 \\
\hline & \multirow{2}{*}{$\begin{array}{l}\text { Kendi kendini } \\
\text { yönlendiren } \\
\text { kariyer }\end{array}$} & $\begin{array}{l}\text { Varyansların } \\
\text { Eşitliği }\end{array}$ & 2.818 & .005 & Akademik & 5.7248 \\
\hline & & $\begin{array}{l}\text { Varyansların } \\
\text { Eşitsizliği } \\
\end{array}$ & 2.803 & .005 & İdari & 5.3942 \\
\hline & \multirow{2}{*}{$\begin{array}{l}\text { Değer } \\
\text { yönelimli } \\
\text { kariyer }\end{array}$} & $\begin{array}{l}\text { Varyansların } \\
\text { Eşitliği }\end{array}$ & 3.044 & .002 & Akademik & 5.4637 \\
\hline & & $\begin{array}{l}\text { Varyansların } \\
\text { Eşitsizliği } \\
\end{array}$ & 3.037 & .003 & İdari & 5.1115 \\
\hline & & & & & & \\
\hline \multirow{2}{*}{ Cinsiyet } & \multirow{2}{*}{ Stresli } & $\begin{array}{l}\text { Varyansların } \\
\text { Eşitliği } \\
\end{array}$ & 3.157 & .002 & Erkek & 4.2890 \\
\hline & & $\begin{array}{l}\text { Varyansların } \\
\text { Eşitsizliği }\end{array}$ & 3.157 & .002 & Kadın & 3.8501 \\
\hline & \multirow{3}{*}{ Zaman baskısı } & & & & & \\
\hline \multirow{2}{*}{$\begin{array}{l}\text { Yaşamın } \\
\text { çoğunun geçtiği } \\
\text { şehir }\end{array}$} & & $\begin{array}{l}\text { Varyansların } \\
\text { Eşitliği }\end{array}$ & -2.551 & .011 & İstanbul & 2.8557 \\
\hline & & $\begin{array}{l}\text { Varyansların } \\
\text { Eşitsizliği }\end{array}$ & -2.388 & 0.18 & $\begin{array}{l}\text { Diğer } \\
\text { şehirler }\end{array}$ & 3.2247 \\
\hline
\end{tabular}

Tablo 5, araştırmaya katılanların demografik özelliklerinden kaynaklı olarak ortaya çıkan farklılıklara ilişkin bulguları göstermektedir. Akademik ya da idari personel olmak, aceleci ve stresli kişilik özellikleri açısından anlamlı farklılıklar meydana getirmektedir. Elde edilen bulgulara göre akademisyenlerin aceleci kişilik özelliklerinin idari personellere göre daha yüksek düzeyde olduğunu ifade etmek mümkündür. Ayrıca, idari personellerin stresli kişilik 
özelliklerinin akademik personele göre daha yüksek düzeyde olduğu ifade edilebilir. Akademik personeller ile idari personellerin çok yönlü kariyer tutumları arasında istatistiki açıdan anlamlı farklılıklar olduğu görülmektedir. Bulgulara göre, akademik personellerin, idari personele göre daha yüksek düzeyde kendi kendini yönlendiren kariyer ve değer yönelimli kariyer eğiliminde oldukları görülmektedir. Stresli kişilik özelliğine sahip olma açısından kadınlar ve erkekler arasında anlamlı farklılıklar olduğu görülmektedir. Erkek çalışanların kişilik özelliği olarak daha stresli bir yapıya sahip olduklarını ifade etmek mümkündür. Yaşantılarının çoğunluğunu İstanbul dişında geçirmiş olan katılımcıların, yaşantısının çoğunu İstanbul'da geçermiş olan katılımcılara göre daha yüksek düzeyde zaman baskısı hisseden bir yapıda oldukları görülmektedir.

Bulgular genel olarak incelendiğinde akademik personellerin daha aceleci kişilik özellikleri, idari personellerin ise daha stresli kişilik özelliklerine sahip oldukları, akademik personelin idari personele göre daha fazla çok yönlü kariyer eğiliminde olduğu görülmektedir. Bunun yanında erkeklerin kadınlardan daha fazla stres yaşadıkları görülmektedir. Elde edilen bulgular göz önüne alındığında kişilik özelliklerinin cinsiyete, görev türüne ve coğrafyaya göre değişimi (Taymur ve Türkaçar, 2012; Zel, 2001) kişiliğin sonradan edinilen kısmını işaret etmektedir. Katılımcıların diğer kişilik özellikleri ise çok yönlü kariyer açısından anlamlı bir etkiye sahip olmamaktadır.

\section{Korelasyon analizi}

Araştırmanın değişkenlerinin arasındaki ilişkilerin incelenmesi için yapılan korelasyon analizi sonuçları Tablo 6'da yer almaktadır.

Tablo 7. Korelasyon analizi

\begin{tabular}{|c|c|c|c|c|c|c|}
\hline & & \begin{tabular}{|l} 
Zaman \\
kullanım \\
eğilimi \\
\end{tabular} & Aceleci & Stresli & \begin{tabular}{|l} 
Zaman \\
bask1s1 \\
hisseden
\end{tabular} & Özgüvenli \\
\hline \multirow{3}{*}{$\begin{array}{l}\text { Zaman } \\
\text { kullanım } \\
\text { eğilimi }\end{array}$} & \begin{tabular}{|l|} 
Pearson \\
Korelasyon
\end{tabular} & \multirow{3}{*}{1} & $-.309^{* *}$ & $.135^{* *}$ & $.156^{* *}$ & $-.103^{*}$ \\
\hline & $\begin{array}{l}\begin{array}{l}\text { Anlamlilik } \\
\text { kuyruk) }\end{array} \\
\end{array}$ & & .000 & .008 & .002 & .043 \\
\hline & $\mathrm{N}$ & & 387 & 387 & 387 & 387 \\
\hline \multirow{3}{*}{$\begin{array}{l}\text { Kendi kendini } \\
\text { yönlendiren } \\
\text { kariyer }\end{array}$} & \begin{tabular}{|l} 
Pearson \\
Korelasyon \\
\end{tabular} & .023 & $.120^{*}$ & $.122^{*}$ & -.039 & -.075 \\
\hline & $\begin{array}{l}\begin{array}{l}\text { Anlamlilik } \\
\text { kuyruk) }\end{array} \\
\end{array}$ & .648 & .019 & .017 & .450 & .139 \\
\hline & Kişi & 387 & 387 & 387 & 387 & 387 \\
\hline \multirow{3}{*}{$\begin{array}{l}\text { Değer } \\
\text { yönelimli } \\
\text { kariyer }\end{array}$} & \begin{tabular}{|l} 
Pearson \\
Korelasyon \\
\end{tabular} & -.012 & $.138 * *$ & .017 & -.041 & $-.124^{*}$ \\
\hline & \begin{tabular}{|l}
$\begin{array}{l}\text { Anlamll11k } \\
\text { kuyruk) }\end{array}$ \\
\end{tabular} & .809 & .007 & .739 & .418 & .015 \\
\hline & Kişi & 387 & 387 & 387 & 387 & 387 \\
\hline
\end{tabular}

Katılımcıların zaman kullanım eğilimleri, kişilik özellikleri ve çok yönlü kariyer niyetleri arasındaki ilişkilerin belirlenmesi için yapılan korelasyon analizi sonuçları Tablo 6'da yer almaktadır. Katılımcıların zaman kullanım eğilimleri (Polikroniklik ve Monokroniklik) ile kişilik özellikleri arasındaki ilişkiler incelendiğinde; çalışanların zaman kullanım eğilimleri ile aceleci kişilik özellikleri arasında düşük düzeyde, ters yönlü ve istatistiki olarak anlamlı 
bir ilişski olduğu görülmektedir. Ayrıca stresli kişilik, zaman baskısı hissetme ve özgüvenli olma ile zaman kullanımı arasında çok düşük düzeyde anlamlı ilişkiler tespit edilmiştir. Özgüvenli olma ile zaman kullanım eğilimi arasında ortaya çıkan ilişki ters yöndedir. Elde edilen sonuçlar Arndt vd. (2006)'nin çalışmasında belirtmiş olduğu görüşler ile benzerdir. Zaman kullanımı ile stres arasındaki ilişkiler Frei vd. (1998) tarafından yapılan çalışma sonuçları ile benzerdir. Katılımcıların zaman kullanım eğilimleri ile çok yönlü kariyer tercihleri arasında anlamlı bir ilişki tespit edilememiştir. Elde edilen sonuç Jang ve George (2012) ve Arndt vd. (2006) tarafından yapılan çıkarımlardan farklılık göstermektedir.

Aceleci kişilik özelliği ile çok yönlü kariyer tercihleri boyutları arasında pozitif yönde, çok düşük düzeyde ve istatistiki olarak anlamlı ilişkiler tespit edilmiştir. Stresli kişilik özelliği ile kendi kendini yönlendiren kariyer arasında pozitif yönlü, çok düşük düzeyde ve istatistiki olarak anlamlı ilişki, özgüvenli kişilik özelliği ile değer yönelimli kişilik özelliği arasında ters yönde çok düşük düzeyde ve istatistiki olarak anlamlı ilişki tespit edilmiştir. Sonuçlar genel olarak incelendiğinde, aceleci ve stresli kişilik özelliklerine sahip olma ile çalışanların kendi kariyerlerini kendilerinin yönlendirdiklerini düşünmeleri arasında düşük düzeyde ilişki bulunmaktadır. Kendi kariyerinde kendi söz hakkının olduğunu düşünme ile stresli kişilik özelliği arasında meydana gelen düşük düzeyli ilişki, Gümüştekin ve Gültekin (2009) tarafından bireyin strese duyarlılığına bağlı olarak kariyerini yönlendirme eğilimine girmesi ile açıklanabilmektedir. Aceleci ve özgüvenli kişilik özelliklerine sahip olma ile içsel unsurlara bağlı olarak kariyer seçimi yapma (değer yönelimli kariyer) arasında yine düşük düzeyde ilişki bulunmaktadır. Ancak özgüvenli kişilik özelliği ile değer yönelimli kariyer seçimi arasındaki ilişki ters yönlüdür. Yani, özgüvenli olma açısından değerlendirilecek olursa, özgüvenli kişilik özelliğinin çalışanları değer yönelimli kariyer seçiminden uzaklaştırdığını düşünmek mümkündür. Korelasyon analizi sonuçları ile alanyazında yer alan çalışma sonuçları birlikte incelendiğinde (Negru-Subtirica ve Pop, 2016; Taş ve Özmen, 2019) kariyer seçimi ile kişilik özellikleri arasında benzer ilişkilerin olduğu görülmektedir. Değişkenler arasındaki ilişkileri yorumlamada Tablo 3'te yer alan tanımlayıcı istatistiklerin de faydalı olacağı düşünülmektedir. Örneğin katılımcıların özgüvenli kişilik özelliklerinin yüksek seviyede olmaması, çok yönlü kariyer seçiminde bireyin kendine yatırım yapma ve psikolojik sözleşmeyi kendisi ile yapması (Hall, 1996; Kale ve Özer, 2012) özgüven ile değer yönelimli kariyer arasındaki ters yönlü ilişkiyi açıklayabilir. Son olarak zaman kullanımı ve kişilik özellikleri arasında düşük düzeyde ilişkiler, çok yönlü kariyer ile kişilik özellikleri arasında düşük düzeylerde ilişkiler tespit edilirken, zaman kullanımı ile çok yönlü kariyer arasında ise anlamlı bir ilişki tespit edilememiştir. Değişkenler arasındaki ilişsilerin düşük olmasından dolayı regresyon analizi yapılmamıştır. Değişkenler arasındaki ilişkilerden hareketle araştırma hipotezlerinin desteklenme ve desteklenmeme durumları şu şekildedir;

\begin{tabular}{ll}
\hline H1: Çalışanların zaman kullanım eğilimleri ile kişilik tipleri arasında anlamlı bir & Desteklendi \\
ilişki vardır. & \\
\hline $\begin{array}{l}\text { H2: Çalışanların çok yönlü kariyer tercihleri ile kişilik tipleri arasında anlamlı bir } \\
\text { ilişki vardır. }\end{array}$ & $\begin{array}{l}\text { Kısmen } \\
\text { Desteklendi }\end{array}$ \\
\hline H3: Çalışanların çok yönlü kariyer tercihleri ile zaman kullanım eğilimleri & Desteklenmedi \\
arasında anlamlı bir ilişki vardır. & \\
\hline
\end{tabular}




\section{SONUÇ, TARTIŞMA ve ÖNERİ}

Araştırmada, vakıf yükseköğretim kurumlarındaki akademik ve idari personelin çok yönlü kariyer eğilimlerinde personellerin kişilik özelliklerinin ve zaman kullanım eğilimlerinin rolünün tespit edilmesi amaçlanmıştır. Araştırma, kavramsal ilişkileri tam olarak sağlayan bir alanyazın olmamasından dolayı keşfedici özelliktedir. Araştırmada öncelikle çalışanların çok yönlü kariyer eğilimleri, zaman kullanım eğilimleri ve kişilik özelliklerinin hangi düzeyde olduğu incelenmiştir. Bulgulara göre, çalışanların polikronik zaman kullanım eğiliminde oldukları görülmektedir. Yani çalışanlar aynı anda birden fazla görevi üstlenmekten hoşlanan, görevler arasında geçiş yapabilen kişilerden oluşmaktadır. Akademik ve idari personellerin görev yapıları düşünüldüğünde birbirinden farklı işleri sırasız olarak yapabilme eğilimlerinin polikronikle bağdaştığını düşünmek mümkündür. Özellikle akademisyenlerin gün içinde ders anlatma, akademik çalışmalar yapma ve öğrenci danışmanlıkları gibi farklı işleri yaptıkları düşünüldügünde akademisyenlerin polikroniklik eğilimlerini anlamlandırmak mümkündür. Çalışmada akademik ve idari personellerin kişilik özelliklerinin belirlenmesi ve A-B tipi kişilik özelliklerine yakınlıkları incelenmiştir. Çalışanların A ya da B kişilik tiplerine tam olarak ayrılmadığı görülmektedir. Bulgulara göre, çalışanların acelecilik özelliklerinin orta düzeyin üzerinde, stresli kişilik özelliklerinin baskın, zaman baskısı hissetme düzeylerinin düşük ve özgüvenli kişilik özelliklerinin çok yüksek olmadığ görülmüştür. Sonuç alanyazında yer alan bilgilerle uyumludur. Moorhead ve Griffin (1992) bireylerin nadiren A ya da B kişilik özelliklerini tam olarak taşıdıklarını, çoğunlukla iki kişilik özelliğini de taşıyabildiklerini ifade etmişlerdir. Araştırmada, diğer araştırmalardan farklı olarak kişilik özellikleri A ve B kişilik tipolojilerine indirgenmekten çok, çalışanların kişilik tipolojilerinin altında yatan kişilik özellikleri açısından değerlendirilmektedir. Çalışanların kişilik özellikleri alanyazına uygun şekilde; aceleci, stresli, zaman baskısı hisseden, özgüvenli şeklinde incelenmiştir. Böylece tek bir kişilik tipinden çok kişiliklerin bazı özellikleri ile incelemeler gerçekleştirilmiştir. Polikronik zaman eğiliminin yüksek olmasına rağmen zaman baskısı hissetme özelliğinin düşük olması, çalışanların içsel olarak iş akışını kabullenmiş olmaları ile açıklanabilir. Çalışanların işin özelliklerini benimsemiş olması, polikroniklik seviyelerini arttırırken zaman baskısını azaltmış olabilir. Çalışanların çok yönlü kariyer algılarının çok yüksek düzeyde olumlu olduğu tespit edilmiştir. Çalışılanların üniversite personeli olmaları, mesleki olarak yeniliklere açık olmaları, belirli seviyede eğitime sahip olmaları, hem akademik hem de idari personellerin diğer üniversiteler hakkında bilgilere kolayca erişebiliyor olmaları, akademisyenlerin (araştırma alanlarına göre değişmekle birlikte) sektörel gelişmelerden kolayca haberdar olabilmeleri gibi unsurlar düşünüldüğünde, çok yönlü kariyer eğilimlerini anlamlandırmak kolaylaşabilmektedir. Ayrıca çok yönlü kariyer eğiliminde çalışanların kendi gelişimlerine daha fazla yönelmeleri kısmen de olsa çalışanların yüksek eğitim seviyeleri ile ilişkilendirilebilir.

Çalışanların demografik özelliklerine bağlı olarak çok yönlü kariyer, zaman kullanım eğilimleri ve kişilik özelliklerinde meydana gelen farklılıkların tespit edilmesi, söz konusu değişkenlerin çerçevesini daha iyi anlamlandırılmasına olanak sağlayabilecektir. Yapılan fark testleri sonucunda zaman kullanım eğilimi hakkında herhangi bir demografik özellik açısından anlamlı bir farklılığa ulaşılamamıştır. Görev türü açısından ise; akademisyenlerin idari personellere göre daha fazla aceleci, idari personellerin ise daha fazla stresli kişilik özelliklerine sahip oldukları sonucuna ulaşılmıştır. Akademik personellerin idari personellerden daha yüksek düzeyde çok yönlü kariyer planlamasında olduğu görülmektedir. Akademik süreçlerin içsel olarak rekabetçi yapı gerektirmesi (akademik yayın sayısı, kadro 
alma çabası, yükselmelerin unvanlara bağlı olabilmesi gibi faktörler) akademisyenlerin idari personellere göre daha aceleci kişilik özellikleri taşımalarını açıklayabilir. Örneğin, bir unvanın geç alınması, akademik gelecekte fırsatların kaçırılmasına neden olabilir. Diğer sonuçlara göre; erkekler kadınlara göre daha yüksek stresli kişilik özellikleri göstermekte, yaşamlarının çoğunluğunu İstanbul dışında geçirmiş olan kişiler, İstanbul'da geçirmiş olanlara göre daha fazla zaman baskısı hissetmektedir. Aydoğan (2005) metropol hayatını hareket alanı, görece daha küçük yerleşimleri ise yavaşlık ve dinginlik alanı olarak tanımlamaktadır. Yazarın tanımlaması ve özellikle İstanbul'un yapısı birlikte düşünüldüğünde diğer kentlerde yaşamaya alışmış insanların zaman baskısı hissetmeleri daha kolay anlamlandırılabilir.

Zaman kullanım eğilimi, kişilik özellikleri ve çok yönlü kariyer eğilimi arasındaki ilişkiler incelendiğinde, zaman kullanım eğilimi ve kişilik özellikleri arasında düşük düzeyde anlamlı ilişkiler görülmektedir. A-tipi kişilik özellikleri (geç kalmama, hızlı konuşma, hızlı yeme, zaman baskısı hissetme, sabırsız olma) ve zaman kullanım eğilimi özellikleri (aynı anda birden fazla işle uğraşma, bu uğraşının verimlilik ile ilişkilendirilmesi, kısa zaman bloğunda işler arası geçişin eğlenceli algılanması) birlikte düşünüldüğünde, kişilik özellikleri ile zaman kullanımı arasında ortaya çıkan ilişki olağan karşılanabilir. Özellikle vakıf yükseköğretim kurumlarında iş akışlarının hızlı olması, çalışanların zaman tutumlarını açıklama konusunda yardımcı olabilir. Çok yönlü kariyer eğilimi ile kişilik özellikleri (aceleci kişilik, stresli, özgüvenli kişilik özellikleri) arasındaki ilişkiler ise düşük düzededir. Çalışanların aceleci kişilik özellikleri ile çok yönlü kariyer arasındaki düşük düzeyli ilişki daha önce de belirtildiği gibi görev dinamikleri ile açıklanabilir. Kendi kariyerinde kendi söz hakkının olduğunu düşünme ile stresli kişilik özelliği arasında meydana gelen düşük düzeyli ilişki, bireyin strese duyarlılığına bağlı olarak kariyerini yönlendirme eğilimine girmesi ile açıklanabilmektedir. Özgüvenli kişilik özellikleri ile değer yönelimli kariyer eğilimi arasındaki ters yönlü ilişki ise, çalışanların işyeri ile olan değer uyumları açısından açıklanabilmektedir. Çalışanların duygularını kolayca gösterememesi, karar vericilerin daha baskın olması çalışanların değer yönelimli kariyerlere yönelme eğilimli olmalarını sağlayabilmektedir. Zaman kullanım eğilimi, kişilik tipleri ve çok yönlü kariyer arasındaki nedensellik ilişkileri, değişkenler arasındaki ilişkilerin düşük olmasından dolayı incelenmemiştir.

Araştırmada değişkenler arasında düşük düzeylerde ilişkiler elde edilmiştir. Özellikle bu araştırmada veri toplama esnasında A-B tipi kişilik ve polikronik-monokronik indirgemesine gidilmemiş olması, sonuçların üzerinde etkili olabilecektir. Çalışmanın dikotom ölçüm araçları ile yenilenmesi farklı sonuçların elde edilmesini sağlayabilecektir. Ayrıca yeniden tasarlanacak çalışmalar için diğer çalışmalarda A-B tipi kişilik ölçeği yerine, 5 faktör kişilik, Enneagram kişilik ölçeği gibi ölçüm araçlarının denenmesinin de sonuçların farklı olmasını sağlayacağı düşünülebilir. Elde edilen sonuçlara göre, özellikle akademisyenlerin ilerleyen dönemlerde kariyerlerini farklı bir örgüt ya da yapı içerisinde yönlendireceklerini öngörme açısından önem taşımaktadır. Özellikle vakıf yükseköğretim kurumlarının, çalışanların gelişimlerini ve psikolojik sözleşmelerini örgüte yönelik olarak geliştirmeleri çalışanların kurumlarında kalmasına fayda sağlayabilecektir. 


\section{KAYNAKÇA}

ARNDT, A., ARNOLD, T.J. ve LANDRY, T.D., (2006). "The Effects of PolychromicOrientation Upon Retail Employee Satisfaction and Turnover", Journal of Retailing 82: 319-330.

ARTHUR, M.B., HALL, D.T. ve LAWRENCE, B.C. (1989). “Generating New Directions in Career Theory: The Case for A Transdisciplinary Approach”, Ed. M.B. Arthur, D.T. Hall ve B.C. Lawrence, The Handbook of Career Theory, New York: Cambridge University, 7-25.

AYDOĞAN, A. (2005). "Şehir ve Cemiyet”. İz Yayıncılık, İstanbul.

BARUCH, Y. ve OSENSTEIN, E. (1992). "Human Resource Management in Israeli Firms: Planning and Managing Careers in High-Technology Organizations", The International Journal of Human Resource Management, 3(3): 477-495.

BluEdorn, A. C., KAlliath, T. J., STRUBE, M. J. ve MARTIN, G. D. (1999). "Polychronicity and the Inventory of Polychronic Values (IPV) The Development of An Instrument to Measure A Fundamental Dimension of Organizational Culture". Journal of managerial psychology, 14(3/4): 205-231.

BRISCOE, J. P. HALL, D. T. ve DEMUTH, R. L. F. (2006). "Protean and Boundaryless Careers: An empirical Exploration", Journal of Vocational Behavior, 69 (1): 30-47.

BRISCOE, J.P. ve HALL, D.T. (2006). "The Interplay of Boundaryless and Protean Careers: Combinations and Implications", Journal of Vocational Behavior, 69: 4-18,

CONTE, J. M. ve GINTOFT, J. N. (2005). "Polychronicity, Big Five Personality Dimensions, and Sales Performance", Human Performance, 18(4): 427-444.

CONTE, J. M., ve JACOBS, R. R. (2003). "Validity Evidence Linking Polychronicity and Big Five Personality Dimensions to Absence, Lateness, and Supervisory Ratings of Performance". Human Performance, 16: 107-129.

ÇALIK, T. ve EREŞ, F. (2006). “Kariyer Yönetimi Tanımlar, Kavramlar, İlkeler”, Gazi Kitabevi, Ankara.

DALGIÇ, A., ve TÜRKOĞLU, N. (2018). "Otel Çalışanlarının İş Becerikliliği ve Polikronisite Eğilimlerinin İşten Ayrılma Niyetleri Üzerine Etkisi”, SETSCI Conference Indexing System, 3: 787-794.

DIRENZO, M.S. GREENHAUS, J.H. ve WEER, C.H. (2015). "Relationship Between Protean Career Orientation and Work-Life Balance: A Resource Perspective", Journal of Organizational Behavior, 36: 538-560.

ERDEM, R., YILDIRIM, H.H., ATİLLA, G., ve OKSAY, A. (2009). "Hastane Çalışanlarının Kişilik Özellikleri ve Zamanı Kullanma Biçimleri”, Hacettepe Sağlık İdaresi Dergisi, 12(2): 105-120.

ERDOĞMUŞ, N. (2003). "Kariyer Geliştirme Kuram ve Uygulama”, Nobel Yayın Dağıtım, Ankara. 
FREI, R. L., RACICOT, B. ve TRAVAGLINE, A. (1998). “The Impact Of Monochronic And Type A Behavior Patterns On Research Productivity And Stress", Journal of Managerial Psychology, 14(5): 374-387.

FRIEDMAN, M. ve ROSENMAN, R. H. (1974). “Type A Behavior and Your Heart”. NY: Fawcett Books.

GÖKDENIZ, İ. ve MERDAN, E. (2011). “Kişilik ile Kariyer Seçimi Arasındaki İlişkinin İncelenmesi”, Aksaray Üniversitesi İIBBF Dergisi, 3(2): 23-36.

GÜMÜŞTEKİN, G. E. ve GÜLTEKİN, F. (2009). "Stres Kaynaklarının Kariyer Yönetimine Etkileri”, Dumlupınar Üniversitesi Sosyal Bilimler Dergisi, 23: 147-158.

HAIR, J. F., BLACK, W. C., BABIN, B. J. ve ANDERSON, R. E. (2014). "Multivariate Data Analysis". 7. Ed. Pearson Education Limited.

HALL, D. T. (1996). "Protean Careers of the 21st Century", Academy of Management Executive, 10: 8-16.

HALL, D. T. (2004). "The Protean Career: A Quarter-century Journey", Journal of Vocational Behavior, 65(1): 1-13.

HERRMANN, A. HIRSCHI, A. ve BARUCH, Y. (2015). "The Protean Career Orientation as Predictor of Career Outcomes: Evaluation of Incremental Validity And Mediation Effects", Journal of Vocational Behavior, 88: 205-214.

HIRSCHI, A., JAENSCH, V. K. ve HERRMANN, A. (2017). "Protean Career Orientation, Vocational Identity, and Self-Efficacy: An Empirical Clarification of Their Relationship", European Journal of Work and Organizational Psychology, 26(2): 208220.

INKSON, K. (2006). "Protean and Boundaryless Career as Metaphors", Journal of Vocational Behaviour, 69(1): 48-63.

JANG, J. ve GEORGE, R. T. (2012). "Understanding The Influence of Polychronicity on Job Satisfaction and Turnover Intention: A Study Of Non-Supervisory Hotel Employees", International Journal of Hospitality Management 31: 588- 595.

KALE, E. ve ÖZER, S. (2012). "İşgörenlerin Çok Yönlü ve Sınırsız Kariyer Tutumları: Hizmet Sektöründe Bir Araştırma”, Eskişehir Osmangazi Üniversitesi İ̇BF Dergisi, 7(2): 173-196.

KANBUR, A. ve SALİHOĞLU, G. H. (2014). "Çalışanların Sınırsız ve Değişken Kariyer Yolculuğunda İşkolikliğin Rolü Üzerine Bir Araştırma”, Manas Sosyal Araştırmalar Dergisi, 3(2): 27-58.

KANTROWITZ, T. M. DARRIN M. GRELLE, JAMES C. BEATY ve MARK B. WOLF (2012). "Time is Money: Polychronicity as a Predictor of Performance Across Job Levels", Human Performance, 25(2): 114-137.

KARLBERG, L., KRAKAU, I., SJÖDÉN, P. O. ve UNDÉN, A. L. (1997). "Psychometric Properties of A Brief Self-Report Type: A Questionnaire for Use in Primary Health Care”. Scandinavian Journal of Primary Health Care, 15(1): 52-56. 
KASPI-BARUCH, O. (2016). "Motivational Orientation as a Mediator in The Relationship Between Personality and Protean And Boundaryless Careers", European Management Journal, 34(2): 182-192.

KOÇAK, O., ETİ, S., ve GÜRSOY, G. (2017). “A ve B Kişilik Tipine Sahip Kamu ve Özel Sektör Çalışanlarının Kişilik Tiplerinin İncelenmesi: Yalova Örneği”, HAK-İŞ Uluslararası Emek ve Toplum Dergisi, 6(15): 380-397.

KURTULUŞ, K. (2014). “Araştırma Yöntemleri”, Türkmen Kitapevi, İstanbul.

LI, H., NGO, H. Y. ve CHEUNG, F. (2019). "Linking Protean Career Orientation and Career Decidedness: Themediating Role of Career Decision Self-Efficacy”, Journal of Vocational Behavior, 115(2019): 1-11.

LINDQUIST, J. D., ve SCARBOROUGH, C. K. (2007). "The Polychronic-Monochronic Tendency Model: Pmts Scale Development and Validation", Time \& Society, 16(2/3):269-301.

MOORHEAD, G. ve GRIFFIN, R., W. (1992). “Organizational Behavior”, Houghton Mifflin Company, Boston.

NEGRU-SUBTIRICA, O. ve POP, E. I. (2016). "Foreshadowing Identities: The Relation Between Achievement Goals and Educational Identity in A Sample of Romanian Emerging Adults". Cognitie, Creier, Comportament/Cognition, Brain, Behavior. 17(1): $1-14$.

ONAY, M. ve VEZNELİ, Z. (2012). "Sınırsız ve Çok Yönlü Kariyer: Akademisyenlerin Kariyer Yaşamı”, Sosyal ve Beşeri Bilimler Dergisi, 4(1): 193-202.

ONAY, M. ve ZEL, U. (2011). "Kişi-Kültür Uyumunun Kariyer Planlaması Üzerindeki Etkileri”, Doğuş Üniversitesi Dergisi, 12 (2): 265-278.

PAKSOY, M., HIRLAK, B. ve BALIKÇI, O. (2017)."Sınırsız ve Çok Yönlü Kariyer Tutumlarının Bazı Demografik Özellikler Açısından İncelenmesi: Adana Örneği”, Javstudies, 3(2): 277-292.

RASTGAR, A. A., EBRAHIMI, E. ve HESSAN, M. (2014). "The Effects of Personality on Protean and Boundaryless Career Attitudes", International Journal of Business Management and Economics, 1(1): 1-5.

REDONDO, R., SPARROW, P. ve HERNANDEZ-LECHUGA, G. (2019). "The Effect of Protean Careers on Talent Retention: Examining The Relationship Between Protean Career Orientation, Organizational Commitment, Job Satisfaction and Intention to Quit for Talented Workers", The International Journal of Human Resource Management, 1-24, DOI: 10.1080/09585192.2019.1579247.

SCARBOROUGH, K. C. ve LINDQUIST, J. D. (1998). "Time Management and Polychronicity: Comparisons, Contrasts, and Insights for The Workplace", Journal of Managerial Psychology 14(3/4): 288-312.

SCHEIN, E.H. (1992). “Organizational Culture and Leadership”, 2nd, San Francisco: JosseyBass. 
SEYMEN, O. A. (2004). "Geleneksel Kariyerden, Sınırsız ve Dinamik/Değişken Kariyere Geçiş: Nedenleri ve Sonuçları Üzerine Yazınsal Bir İnceleme”, Uludağ Üniversitesi İktisadi Ve İdari Bilimler Fakültesi Dergisi, 23(1): 79-114.

SUVACI, B. ve PAŞAOĞLU BAŞ, D. (2018). "Banka Çalışanlarının Çok Yönlü ve Sınırsız Kariyer Tutumları", Çankırı Karatekin Üniversitesi İktisadi Ve İdari Bilimler Fakültesi Dergisi, 8(1): 113-140.

ŞAHIN, N. H., BASIM, H. N. ve AKKOYUN, N. (2011). “A-Tipi Kişilik ve Stres İlişkisinde Üç Önemli Bileşen: Öfke, Etkisiz Başa Çıkma ve İş Saplantısı”, Türk Psikoloji Dergisi, 26(68): 31-44.

TAŞ, M. A. ve ÖZMEN, M. (2019). "Kişilik Tipi ile Kariyer ve Akademik Desteğin Kariyer Uyum Yeteneklerine Etkisi: Bir Saha Araştırması". OPUS-Uluslararası Toplum Araştırmaları Dergisi, 14(20): 333-370.

TAYMUR İ, ve TÜRKÇAPAR M. H. (2012). "Kişilik: Tanımı, Sınıflaması ve Değerlendirmesi”. Psikiyatride Güncel Yaklaşımlar 4: 154-177.

TOKAT, B., KARA, H. ve KARA, M.Y. (2013). “A-B Tipi Kişilik Özelliklerine Sahip İşörrenlerin Olası Bir Örgütsel Değişime Yatkınlıklarının Araştırılması”, Turkish Studies, 8(8): 1973-1988.

ZEL, U. (2001). “Kişilik ve Liderlik”, Seçkin Yayınları, Ankara. 